Research Article

\title{
Effects of Novel Nitric Oxide-Releasing Molecules against Oxidative Stress on Retinal Pigmented Epithelial Cells
}

\author{
Valeria Pittalà,, ${ }^{1}$ Annamaria Fidilio, ${ }^{2}$ Francesca Lazzara, ${ }^{2}$ Chiara Bianca Maria Platania, ${ }^{2}$ \\ Loredana Salerno, ${ }^{1}$ Roberta Foresti, ${ }^{3,4}$ Filippo Drago, ${ }^{2,5}$ and Claudio Bucolo ${ }^{2,5}$ \\ ${ }^{1}$ Department of Drug Sciences, University of Catania, Catania, Italy \\ ${ }^{2}$ Department of Biomedical and Biotechnological Sciences, Section of Pharmacology, School of Medicine, University of Catania, \\ Catania, Italy \\ ${ }^{3}$ Inserm U955, Equipe 12, 94000 Créteil, France \\ ${ }^{4}$ Université Paris Est, Faculté de Médecine, 94000 Créteil, France \\ ${ }^{5}$ Center for Research in Ocular Pharmacology - CERFO, University of Catania, Catania, Italy
}

Correspondence should be addressed to Claudio Bucolo; claudio.bucolo@unict.it

Received 29 June 2017; Accepted 27 August 2017; Published 12 October 2017

Academic Editor: Adrian Smedowski

Copyright (C) 2017 Valeria Pittalà et al. This is an open access article distributed under the Creative Commons Attribution License, which permits unrestricted use, distribution, and reproduction in any medium, provided the original work is properly cited.

Oxidative stress is a hallmark of retinal degenerations such as age-related macular degeneration and diabetic retinopathy. Enhancement of heme oxygenase-1 (HO-1) activity in the retina would exert beneficial effects by protecting cells from oxidative stress, therefore promoting cell survival. Because a crosstalk exists between nitric oxide (NO) and HO-1 in promotion of cell survival under oxidative stress, we designed novel NO-releasing molecules also capable to induce HO-1. Starting from curcumin and caffeic acid phenethyl ester (CAPE), two known HO-1 inducers, the molecules were chemically modified by acylation with 4-bromo-butanoyl chloride and 2-chloro-propanoyl chloride, respectively, and then treated in the dark with $\mathrm{AgNO}_{3}$ to obtain the nitrate derivatives VP10/12 and VP10/39. Human retinal pigment epithelial cells (ARPE-19) subjected to $\mathrm{H}_{2} \mathrm{O}_{2}$-mediated oxidative stress were treated with the described NO-releasing compounds. VP10/39 showed significant $(p<0.05)$ antioxidant and protecting activity against oxidative damage, in comparison to VP10/12, which in turn showed at $100 \mu \mathrm{M}$ concentration a slight but significant cell toxicity. Only VP10/39 significantly $(p<0.05)$ induced HO-1 in ARPE-19, most likely through covalent bond formation at Cys151 of the Keap1-BTB domain, as revealed from molecular docking analysis. In conclusion, the present data indicate VP10/39 as a promising candidate to protect ARPE-19 cells against oxidative stress.

\section{Introduction}

Oxidative stress plays a key role in the pathogenesis of several eye disorders, such as, age-related macular degeneration (AMD) and diabetic retinopathy (DR) [1-5]. Heme oxygenase-1 (HO-1), also known as heat shock protein 32 (HSP32), is one of the components of cellular defense mechanisms against oxidative stress-mediated injury. The transcription of HO-1 is mediated by the nuclear transcription factor Nrf2, whose protein levels are in turn regulated by the Kelch-like ECH-associated protein 1 (Keap1) [6].

Regarding AMD, the role of $\mathrm{HO}-1$ in disease pathogenesis has been highlighted by genetic association of the $19 \mathrm{G}>\mathrm{C}$
HO-1 gene variant with incidence and progression of AMD. Furthermore, the gene variant $25129 \mathrm{~A}>\mathrm{C}$ of $\mathrm{Nfr} 2$, activator of HO-1 expression, was associated to AMD. Nfr2 $2^{-1}$ mice developed age-dependent degeneration of the RPE and choriocapillaris function, along with spontaneous choroidal neovascularization and deposits of inflammatory proteins in the subretinal space [7]. In this perspective, activation of the Nrf2-HO1 axis would be beneficial for the treatment of AMD.

The inducible $\mathrm{HO}$ isoform, $\mathrm{HO}-1$, is highly expressed in the retina of diabetic rats [8], and increased levels of HO-1 may be a response to oxidative stress in diabetes $[9,10]$. However, it was found that long-term diabetes led to reduced 
HO-1 mRNA levels in the retinal pigmented epithelium (RPE) [11]. Therefore, induction of HO-1 would be beneficial also for the treatment of diabetic retinopathy.

Curcumin and caffeic acid phenethyl ester (CAPE) are nutraceutical substances able to induce the upregulation of HO-1. Studies have shown that curcumin has a wide range of beneficial properties, including anti-inflammatory and antioxidant activities $[12,13]$. The pleiotropic action of curcumin is related to regulation of multiple survival and cytoprotective signaling pathways, including anti-inflammatory pathways and those regulated by $\mathrm{NF} \kappa \mathrm{B}, \mathrm{AKT}$, growth factors, and Nrf2 transcription factor [14-23].

Specifically, low concentrations of curcumin induced HO- 1 expression in RPE cells and decreased reactive oxygen species (ROS) in RPE cells, challenged with hydrogen peroxide [24]. Additionally, curcumin modulated retinal oxidative stress in a rat model of streptozotocin- (STZ-) induced diabetic retinopathy [25]. CAPE exhibited antioxidant [26] and antiinflammatory properties [27] that can be exploited for treatment of several conditions such as ischemia/reperfusion injury [28, 29], atherosclerosis [30] and diabetes [31]. The cytoprotective effect of CAPE against oxidant stress is due to upregulation of HO-1 mRNA [32], through induction of transcription of the ARE-related (antioxidant response element) gene [33]. The mechanism of action of CAPE was confirmed in several in vitro studies $[32,34]$, showing that CAPE significantly increase $\mathrm{HO}-1$ protein expression through inactivation of Nrf2-Keap1 complex and consequent Nrf2 activation [22].

Paeng et al. [35] showed that CAPE inhibits VEGF production in an in vitro model of retinal hypoxia (ARPE-19 cells under hypoxic conditions). Thus, CAPE would reduce retinal neovascularization through inhibition of ROS synthesis and reduction of HIF-1 $\alpha$ and VEGF expression [35].

Another molecule that influences the regulation of $\mathrm{HO}-1$ production is nitric oxide (NO) [36]. This diatomic molecule is recognized as an important intercellular messenger in biological systems, for example, the cardiovascular system and the nervous system, including the retina. NO is synthesized by NO synthase isoforms, expressed by endothelial cells and efferent nitrergic neurons. NO is an important modulator of homeostatic processes in the eye, such as regulation of aqueous humor dynamics, blood flow, retinal neurotransmission, and phototransduction. An imbalance in NO production is associated with pathological states such as inflammatory diseases (uveitis, retinitis) or degenerative diseases (glaucoma, retinal degeneration) [37]. The reduction of the bioavailability of $\mathrm{NO}$, caused, for example, by endothelial dysfunction, increases the production of ROS. However, overproduction of NO could be harmful, such as the sustained NO synthesis by inducible NOS (iNOS), which is expressed in response to an inflammatory event. Therefore, it is difficult to design an effective therapeutic strategy with NO supplementation or NOS inhibition, due to the dual action of NO [38]. However, latanoprostene bunod, a NO-releasing prostaglandin analog, is expected to be approved by FDA in the near future for clinical use in glaucoma [39].
The HO and NOS systems show numerous and several interactions. For instance, both are activated by ROS and cytokines [40] and can activate guanylyl cyclase [41]. On the other hand, $\mathrm{NO}$ can upregulate $\mathrm{HO}$ expression by means of a cGMP-dependent pathway [42]. Datta et al. demonstrated that $\mathrm{NO}$ induces $\mathrm{HO}-1$ and showed that there are interactions between the iNOS and HO-1 pathways [43]. Furthermore, Chen and Maines demonstrated that exposure of HeLa cells to the NO donor, sodium nitroprusside (SNP), induced a concentration and time-dependent increase of HO-1 mRNA and activation of mitogen-activated protein kinases (MAPKs): the ERK (ERK1 and ERK2) and p38 pathways [44].

In this perspective, we designed and synthesized the novel NO-releasing molecules VP10/12 and VP10/39, bearing curcumin and CAPE scaffolds, respectively (Figure 1). These compounds decreased significantly oxidative stress and increased cell viability of ARPE-19 challenged with hydrogen peroxide. VP10/39, the CAPE-NO derivative, was more effective than VP10/12, most likely due to its capability to induce HO-1 in ARPE-19 cells.

\section{Materials and Methods}

2.1. Chemistry, Drugs, Chemicals, and Reagents. Melting points of newly synthesized derivatives were determined with an Electrothermal IA9200 using glass capillary tubes. Infrared spectra were recorded on a Perkin-Elmer FT IR 1600 spectrometer in $\mathrm{KBr}$ disks. Elemental analyses for $\mathrm{C}, \mathrm{H}$, and $\mathrm{N}$ were within $70.4 \%$ of theoretical values and were performed on a Carlo Erba Elemental Analyzer Mod. 1108 apparatus. ${ }^{1} \mathrm{H}$ NMR spectra were recorded at $200 \mathrm{MHz}$ on a Varian Inova Unity 200 spectrometer in DMSO- $d_{6}$ or chloroform- $d$ solution. Chemical shifts are given in $\delta$ values (ppm), using tetramethylsilane as the internal standard; coupling constants $(J)$ are given in hertz $(\mathrm{Hz})$. Signal multiplicities are characterized as $\mathrm{s}$ (singlet), $\mathrm{d}$ (doublet), $\mathrm{t}$ (triplet), $\mathrm{q}$ (quartet), $m$ (multiplet), and br (broad signal). All the synthesized compounds were tested for purity on TLC (aluminum sheet coated with silica gel F254, Merck) and visualized by UV ( $\lambda 254$ and $366 \mathrm{~nm}$ ).

2.1.1. Synthesis of bis-4-[4-(Nitrooxy)-1-Butoxy]-Caffeic Acid Phenethyl Ester (VP10/39). A solution of 4-bromobutanoyl chloride $(2.5 \mathrm{mmol})$ and $N, N$-diisopropylethylamine $(2.5 \mathrm{mmol})$ in $1 \mathrm{~mL}$ of anhydrous THF was slowly added to a solution of CAPE $(1 \mathrm{mmol})$ in $5 \mathrm{~mL}$ of anhydrous THF, cooled at $0^{\circ} \mathrm{C}$, and under a nitrogen atmosphere. Following the addition, the reaction mixture was left stirring at room temperature for $1 \mathrm{~h}$. The obtained solution was diluted with $70 \mathrm{~mL}$ of EtOAc and the organic layer was washed with water $(2 \times 50 \mathrm{~mL})$ and brine $(1 \times 50 \mathrm{~mL})$, dried over anhydrous $\mathrm{Na}_{2} \mathrm{SO}_{4}$, filtered, and evaporated. The crude material was dissolved in $7 \mathrm{~mL}$ of $\mathrm{CH}_{3} \mathrm{CN}, 2.5 \mathrm{mmol}$ of $\mathrm{AgNO}_{3}$ was added, and the mixture was left stirring at reflux for $3 \mathrm{~h}$, in the dark. The obtained suspension was filtered and evaporated (Figure 2). The residue was purified by flash chromatography on silica gel 60 using a mixture of cyclohexane/EtOAc $(7 / 3, v / v)$ as an eluent. Homogeneous fractions were combined and 
<smiles>COc1cc(/C=C/C(=O)/C=C(O)/C=C/c2ccc(OC(=O)OC(C)O[N+](=O)[O-])c(OC)c2)ccc1OC(=O)OC(C)O[N+](=O)[O-]</smiles>

VP10/12<smiles>O=C(/C=C/c1ccc(OC(=O)CCCO[N+](=O)[O-])c(OC(=O)CCCO[N+](=O)[O-])c1)OCCc1ccccc1</smiles>

VP10/39

FIGURE 1: Chemical structure of the synthesized NO-releasing caffeic acid phenethyl ester (VP10/39) and NO-releasing curcumin (VP10/12).

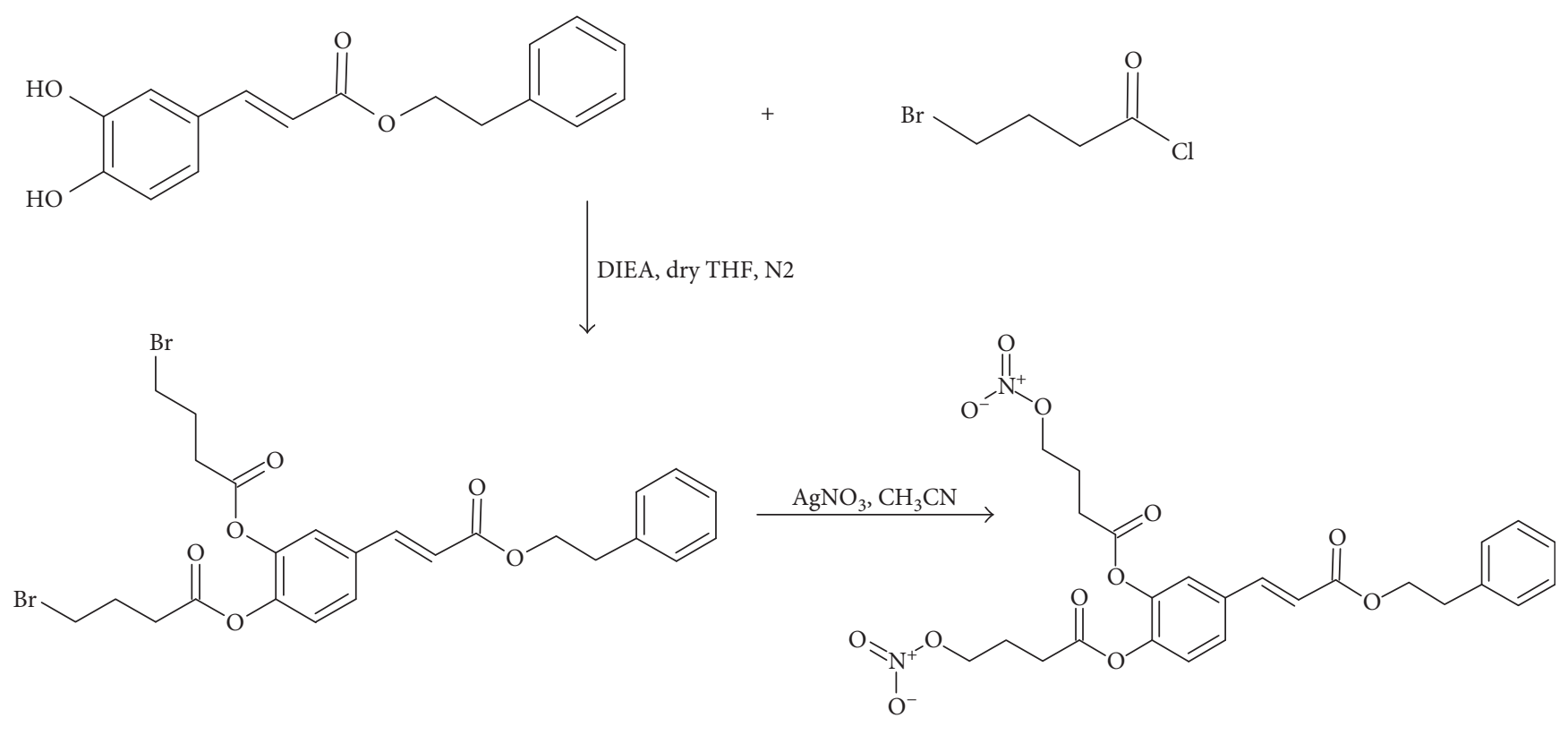

VP10/39

Figure 2: Synthesis of NO-releasing CAPE (VP10/39).

evaporated under reduced pressure to give the title compound $(0.38 \mathrm{~g}$, yield $70 \%)$ as a pure light-yellow oil: IR (KBr) $\mathrm{cm}^{-1} 2959,1770,1712,1635,1505,1280,1172,1112$, 869; ${ }^{1} \mathrm{H}$ NMR (DMSO- $\left.d_{6}\right): \delta \quad 7.79-7.57(\mathrm{~m}, 2 \mathrm{H}+1 \mathrm{H}$, aromatic $+\mathrm{CH}=\mathrm{CHCOO}), 7.39-7.18(\mathrm{~m}, 6 \mathrm{H}$, aromatic $)$, $6.63(\mathrm{~d}, J=16 \mathrm{~Hz}, 1 \mathrm{H}, \mathrm{CH}=\mathrm{CHCOO}), 4.64(\mathrm{t}, J=6.4 \mathrm{~Hz}$, $\left.2 \mathrm{H}, \mathrm{CH}_{2} \mathrm{CH}_{2} \mathrm{CH}_{2} \mathrm{ONO}_{2}\right), 4.60\left(\mathrm{t}, J=6.4 \mathrm{~Hz}, 2 \mathrm{H}, \mathrm{CH}_{2} \mathrm{CH}_{2} \mathrm{CH}_{2}\right.$ $\left.\mathrm{ONO}_{2}\right), 4.37 \quad\left(\mathrm{t}, \quad J=6.8 \mathrm{~Hz}, \quad 2 \mathrm{H}, \quad \mathrm{COOCH}_{2} \mathrm{CH}_{2}\right), \quad 2.97$ $\left(\mathrm{t}, J=6.8 \mathrm{~Hz}, 2 \mathrm{H}, \mathrm{COOCH}_{2} \mathrm{CH}_{2}\right), 2.80-2.67(\mathrm{~m}, 2 \mathrm{H}+2 \mathrm{H}$, $\mathrm{CH}_{2} \mathrm{CH}_{2} \mathrm{CH}_{2} \mathrm{ONO}_{2}$ ), 2.12-1.94 (m, $2 \mathrm{H}+2 \mathrm{H}, \mathrm{CH}_{2} \mathrm{CH}_{2} \mathrm{CH}_{2}$ $\left.\mathrm{ONO}_{2}\right)$. Anal. $\left(\mathrm{C}_{25} \mathrm{H}_{26} \mathrm{~N}_{2} \mathrm{O}_{12}\right) \mathrm{C}, \mathrm{H}, \mathrm{N}$.

2.1.2. Synthesis of [(1E,6E)-3,5-Dioxohepta-1,6-Diene-1,7Diyl]bis-2-Methoxy-4,1-Phenylene bis[1-(Nitrooxy)Ethyl] Biscarbonate (VP10/12). (1E,6E)-1,7-bis(4-[[[1-(chloro) ethoxy]carbonyl]oxy]-3-methoxyphenyl)hepta-1,6-diene3,5-dione $(0.5 \mathrm{mmol})$ was dissolved in $3 \mathrm{~mL}$ of $\mathrm{CH}_{3} \mathrm{CN}$; $1.0 \mathrm{mmol}$ of $\mathrm{AgNO}_{3}$ was added; and the mixture was left stirring at reflux for $3 \mathrm{~h}$, in the dark (Figure 3 ). The obtained suspension was filtered and evaporated. The residue was purified by flash chromatography on silica gel 60 using a mixture of cyclohexane/EtOAc $(7 / 3, v / v)$ as an eluent. Homogeneous fractions were combined and evaporated under reduced pressure to give the title compound $(0.20 \mathrm{~g}$, yield $62 \%)$ as a pure yellow-orange oil: IR $(\mathrm{KBr})$ $\mathrm{cm}^{-1} 2953,2929,2880,1635,1621,1510,1438,1257$, 1027, 870; ${ }^{1} \mathrm{H}$ NMR $\left(\mathrm{CDCl}_{3}\right): \delta 7.62(\mathrm{~d}, J=16 \mathrm{~Hz}, 1 \mathrm{H}$ $+1 \mathrm{H}, \mathrm{ArCH}=\mathrm{CH}), 7.27-7.10(\mathrm{~m}, 6 \mathrm{H}$, aromatic $), 7.02(\mathrm{q}$, $\left.J=5.6 \mathrm{~Hz}, 1 \mathrm{H}+1 \mathrm{H}, \mathrm{CHCH}_{3}\right), 6.58(\mathrm{~d}, J=16 \mathrm{~Hz}, 1 \mathrm{H}+1 \mathrm{H}$, $\operatorname{ArCH}=\mathrm{CH}), 5.87(\mathrm{~s}, 1 \mathrm{H}, \mathrm{COCH}=\mathrm{COH}), 3.91(\mathrm{~s}, 3 \mathrm{H}$ $\left.+3 \mathrm{H}, \mathrm{OCH}_{3}\right), 1.68\left(\mathrm{~d}, \mathrm{~J}=5.6 \mathrm{~Hz}, 3 \mathrm{H}+3 \mathrm{H}, \mathrm{CHCH}_{3}\right)$. Anal. $\left(\mathrm{C}_{27} \mathrm{H}_{26} \mathrm{~N}_{2} \mathrm{O}_{16}\right) \mathrm{C}, \mathrm{H}, \mathrm{N}$.

2.1.3. Synthesis of bis(1-Chloroethyl)[(1E,6E)-3,5-Dioxohepta1,6-Diene-1,7-Diyl]bis-2-Methoxy-4,1-Phenylene Biscarbonate. Curcumin $(2 \mathrm{mmol})$ was dissolved in $20 \mathrm{~mL}$ of ice-cooled 
<smiles>COc1cc(/C=C/C(=O)/C=C(O)/C=C/c2ccc(O)c(OC)c2)ccc1O</smiles>
$\mathrm{NaOH} \quad 1 \mathrm{~N}$<smiles>COc1cc(/C=C/C(=O)/C=C(O)/C=C/c2ccc(OC(=O)OC(C)Cl)c(OC)c2)ccc1OC(=O)OC(C)Cl</smiles><smiles>COc1cc(/C=C/C(=O)/C=C(O)/C=C/c2ccc(OC(=O)OC(C)O[N+](=O)[O-])c(OC)c2)ccc1OC(=O)OC(C)O[N+](=O)[O-]</smiles>

FIGURE 3: Synthesis of NO-releasing curcumin (VP10/12).

$\mathrm{NaOH} 1 \mathrm{~N}$, and 2-chloro-propanoyl chloride $(8 \mathrm{mmol})$ was added (Figure 3). Following the addition, the reaction mixture was left stirring at room temperature for $15 \mathrm{~min}$ and filtered. The obtained crude material was purified by flash chromatography on silica gel 60 using a mixture of cyclohexane/EtOAc $(5 / 5, v / v)$ as an eluent. Homogeneous fractions were combined and evaporated under reduced pressure to give the title compound $(0.32 \mathrm{~g}$, yield $28 \%)$ as a pure yellow solid: $\mathrm{mp} 104-105^{\circ} \mathrm{C}$. IR (KBr) cm $\mathrm{cm}^{-1} 3003,2955,2870$, $1620,1597,1581,1508,1422,1250,1120,770{ }^{1} \mathrm{HNMR}\left(\mathrm{CDCl}_{3}\right)$ : $\delta 7.70(\mathrm{~d}, J=16 \mathrm{~Hz}, 1 \mathrm{H}+1 \mathrm{H}, \mathrm{ArCH}=\mathrm{CH}), 7.38-7.20(\mathrm{~m}, 6 \mathrm{H}$, aromatic), $6.37-7.19(\mathrm{~m}, 1 \mathrm{H}+1 \mathrm{H}+1 \mathrm{H}+1 \mathrm{H}, \quad \mathrm{ArCH}=\mathrm{CH}$ $\left.+\mathrm{CHCH}_{3}\right), 5.95(\mathrm{~s}, 1 \mathrm{H}, \mathrm{COCH}=\mathrm{COH}), 3.99(\mathrm{~s}, 3 \mathrm{H}+3 \mathrm{H}$, $\left.\mathrm{OCH}_{3}\right), 2.00\left(\mathrm{~d}, J=6 \mathrm{~Hz}, 3 \mathrm{H}+3 \mathrm{H}, \mathrm{CHCH}_{3}\right)$. Anal. $\left(\mathrm{C}_{27} \mathrm{H}_{26} \mathrm{Cl}_{2} \mathrm{O}_{10}\right) \mathrm{C}, \mathrm{H}$.

2.2. In Vitro Studies. ARPE-19 (human retinal pigment epithelial) cells were purchased from ATCC ${ }^{\circledR}$. The cell line was cultured at $37^{\circ} \mathrm{C}$ (humidified atmosphere with $5 \% \mathrm{CO} 2$ ), in ATCC-formulated DMEM:F12 medium (ATCC number 30-2006) with $100 \mathrm{U} / \mathrm{mL}$ penicillin, $100 \mu \mathrm{g} / \mathrm{mL}$ streptomycin, and $10 \%$ fetal bovine serum.

ROS were measured with the DCFDA-Cellular Reactive Oxygen Species Detection Assay Kit (ab113851)_according to manufacturer's protocol. DCFDA, a cell permeable fluorogenic dye, is deacetylated by cellular esterases to a nonfluorescent compound and later oxidized by ROS into highly fluorescent 2, $2^{\prime}$-dichlorofluorescein (DCF); fluorescence intensity is proportional to cell ROS concentration. ARPE19 cells were plated into 96 -well black plates $\left(2 \times 10 E^{4}\right.$ cells per well), and confluence was reached within $24 \mathrm{~h}$. After confluence, cells were washed twice with phosphatebuffered saline (PBS pH7.4) and incubated with $25 \mu \mathrm{M}$ DCFDA in buffer solution (provided with the kit) at $37^{\circ} \mathrm{C}$ for 45 minutes. After two washes with PBS, cells were treated with increasing concentrations of VP10/39 and VP10/ $12(1-10-20-100 \mu \mathrm{M})$ for 60 minutes, then oxidative stress was induced with $500 \mu \mathrm{M} \mathrm{H}_{2} \mathrm{O}_{2}$ treatment for 120 minutes. ROS concentration was measured by detection of DCF fluorescence $\left(\lambda_{\text {ex }}=495 \mathrm{~nm}, \lambda_{\mathrm{em}}=529 \mathrm{~nm}\right)$ with a Varioskan ${ }^{\mathrm{TM}}$ Flash Multimode Reader.

Lactate dehydrogenase (LDH) cell release was measured using the Cytotoxicity Detection KitPLUS (LDH) (ROCHE 04744934001) according to manufacturer's protocol. LDH is released into the medium when the integrity of the cell membrane is lost; therefore, high levels of $\mathrm{LDH}$ are indices of cell death. ARPE-19 cells were plated into 96-well plates $\left(1.5 \times 10 E^{4}\right.$ cells per well). After cell confluence was reached $(24 \mathrm{~h})$, cells were treated with increasing concentrations of VP10/39 and VP10/12 (1-10-20-100 $\mu \mathrm{M})$ for 60 minutes and cell damage was induced by $2 \mathrm{mM} \mathrm{H}_{2} \mathrm{O}_{2}$ for 60 minutes. Cell-free culture supernatant was collected in empty plates and incubated with the enzymatic reaction mixture for 30 minutes. LDH was quantified by measuring absorbance at $490 \mathrm{~nm}$ with the Varioskan Flash Multimode Reader.

ATP is present in metabolically active cells and its concentration declines when cell necrosis and apoptosis occur. After oxidative stress induction by treatment with $\mathrm{H}_{2} \mathrm{O}_{2}$, ATP production was measured using the ATPlite 1 step kit (Perkin Elmer 6016731), according to manufacturer's protocol. ATP concentration is proportional to luminescence intensity related to ATP reaction with luciferase and Dluciferin. ARPE-19 cells were plated into 96-well white plates $\left(1.5 \times 10 E^{4}\right.$ cells per well). Cells were treated with increased concentrations of VP10/39 and VP10/12 (1-10-20-100 $\mu \mathrm{M})$ for 60 minutes, then oxidative stress was induced with $1.5 \mathrm{mM} \mathrm{H}_{2} \mathrm{O}_{2}$ for 180 minutes. After that, the plate was equilibrated at room temperature $\left(20-22^{\circ} \mathrm{C}\right)$, before addition of the reaction solution; therefore, luminescence was measured with Varioskan Flash Multimode Reader. 
2.3. Heme Oxygenase Activity Assay. ARPE-19 cells were cultured in $100 \mathrm{~mm}$ diameter petri dishes and were collected 6 hours after incubation with VP10/12 and VP10/39 at $10 \mu \mathrm{M}$ and $20 \mu \mathrm{M}$ concentrations. The heme oxygenase activity assay was then carried out on the basis of the spectrophotometric determination of bilirubin as the final product of heme degradation by heme oxygenase as described previously by Foresti et al. [45]. Collected cells were incubated with hemin, NADPH, and liver cytosol (a source of biliverdin reductase); the reaction was carried out at $37^{\circ} \mathrm{C}$ in the dark and was stopped after $1 \mathrm{~h}$ with an addition of chloroform, used in order to extract the produced bilirubin. Heme oxygenase activity is expressed as picomoles of bilirubin/mg protein/60 $\mathrm{min}$.

2.4. Statistical Analysis. All results were reported as mean \pm SD. Statistical analysis was carried out using 1-way ANOVA followed by Tukey-Kramer multiple comparison test. Differences between two groups were considered as significant given a $p$ value $<0.05$. Graphs were done using GraphPad Prism 5 software (GraphPad Inc., San Diego, CA) that was also used for statistical analysis.

2.5. Molecular Modeling. Activation of the Nrf2 pathway occurs with inhibition of the KEAP1/Nrf2 protein-protein interaction or Keap1 dimerization. Therefore, Nrf2 inducers act by

(i) disrupting the Keap1-DC domain/Nfr2 interaction [46];

(ii) covalent binding to cysteine residues of the Keap1BTB domain [47].

We investigated the binding of VP10/12 and VP10/39 at Keap1-DC and Keap1-BTB with a molecular modeling approach. The whole human Keap1 dimer was built with the advanced molecular modeling task of Maestro $(c)$ and subjected to loop optimization and two energy minimization steps: rigid body energy and all-atom energy minimization using the VSGB 2.0 solvation model [48]. BTB and IVR domains of Keap1 were modeled on the basis of BTB and BACK (IVR) domains of Keltch11 (PDB:3I3N); the DC domain of Keap1 was modeled using the PDB:1X2R X-ray structure as template. The quality of the model was assessed by determination of protein Ramachandran plots before and after energy minimization; the two energy minimization steps led to a significant decrease of residue dihedral violations (Figure 1S supplemental material available online at https://doi.org/10.1155/2017/1420892). Superimposition between the model of human Keap1 dimer with the electron microscopy reconstruction map $(24 \AA)$ of murine Keap 1 dimer [49] was carried out with Chimera 1.11.2 (Figure 2S supplemental material). RMSD between human Keap1 dimer model and electron microscopy map of murine Keap1 was $4.5 \AA$. VP10/12 and VP10/39.sdf files were built with the web server "Online SMILES Translator and Structure File Generator" https://cactus.nci.nih.gov/translate/. Tridimensional structures of these two ligands, tautomerization and ionization at $\mathrm{pH} 7.4$, were obtained by launching the LigPrep task of Schrodinger@ Maestro. Molecular docking of curcumin and CAPE was carried out in order to compare binding of novel synthetized compounds with other known Nrf2 inducers. We used the following docking protocol on the Keap1-DC domain [46]: (i) grid generation on the centroid of the binding pocket; (ii) standard precision (SP) docking (Schrodinger@) performed with Glide (Schrodinger@). At first, docking was carried out with ring conformation sampling, followed by a 500-step conjugate gradient minimization by Glide (dielectric $=1$ ). Covalent docking of VP10/12 and VP10/39 was carried out at the BTB domain of Keap1 as follows: Cys 151 was set as reactive residue and the Michael's addition reaction was simulated [47] with CovDock task of Schrodinger@ Maestro [50]. MMGBSA rescoring of semiflexible docking at the DC domain and covalent docking at BTB was carried out with Schrodinger@ Maestro: the VSGB 2.0 model was used and all residues within $10 \AA$ from ligand were allowed to move.

\section{Results}

3.1. Chemical Synthesis of NO-Releasing Curcumin (VP10/12) and NO-Releasing CAPE (VP10/39). Hybrid NO-releasing molecules were obtained in high yield by using an efficient synthetic route (Figures 2 and 3). The alcoholic-free groups of CAPE and curcumin were firstly acylated with 4-bromobutanoyl chloride or 2-chloro-propanoyl chloride, respectively. In a subsequent step, the intermediates were converted into the corresponding nitrate derivatives by the treatment with $\mathrm{AgNO}_{3}$ at reflux into the dark. The desired final products, VP10/12 and VP10/39, were easily obtained by flash chromatography purification. VP10/12 was obtained in a high overall yield, 70\% two steps; on the contrary, VP10/39 was obtained in poor yield because it is easily hydrolyzed under purification conditions.

3.2. VP10/12 and VP10/39 Protected ARPE-19 Cells from Oxidative Stress. We tested the antioxidant properties of VP10/12 and VP10/39 in ARPE-19 cells, challenged with $\mathrm{H}_{2} \mathrm{O}_{2}$. Treatment with $\mathrm{H}_{2} \mathrm{O}_{2}$ induced oxidative stress by increasing ROS concentration ([ROS]) in ARPE-19 cells (Figures 4(a) and 4(b)). While, pretreatment (60 min) with VP10/12 and VP10/39 decreased significantly $(p<0.05)$ [ROS] in ARPE-19 subjected to oxidative stress (Figures 4(a) and $4(\mathrm{~b}))$. The CAPE-NO derivative, VP10/39, at $1 \mu \mathrm{M}$ concentration induced a 1.5 -fold decrease of [ROS]. Furthermore, $10 \mu \mathrm{M}$ VP10/39 decreased ROS concentration to values of negative control cells (CTRL-), 8.7 $\pm 0.8 \mathrm{FU}$ and 2.9 $\pm 0.4 \mathrm{FU}$, respectively ( $\mathrm{FU}=$ fluorescent units, Figure $4(\mathrm{~b})$ ). The curcumin-NO derivative VP10/12 induced at $1 \mu \mathrm{M}$ concentration a significant 2-fold decrease of [ROS] in ARPE-19 cells treated with $\mathrm{H}_{2} \mathrm{O}_{2}$. Additionally, VP10/12 inhibited ROS formation in a dose-dependent manner. VP10/12 did not decrease [ROS] to levels of negative control cells, in contrast to data obtained for VP10/39.

We analyzed the $\mathrm{LDH}$ release in medium of ARPE-19 challenged with $\mathrm{H}_{2} \mathrm{O}_{2}$, in order to assess the protective effects of tested compounds on cell death induced by oxidative stress. VP10/12 and VP10/39 significantly $(p<0.05)$ induced 


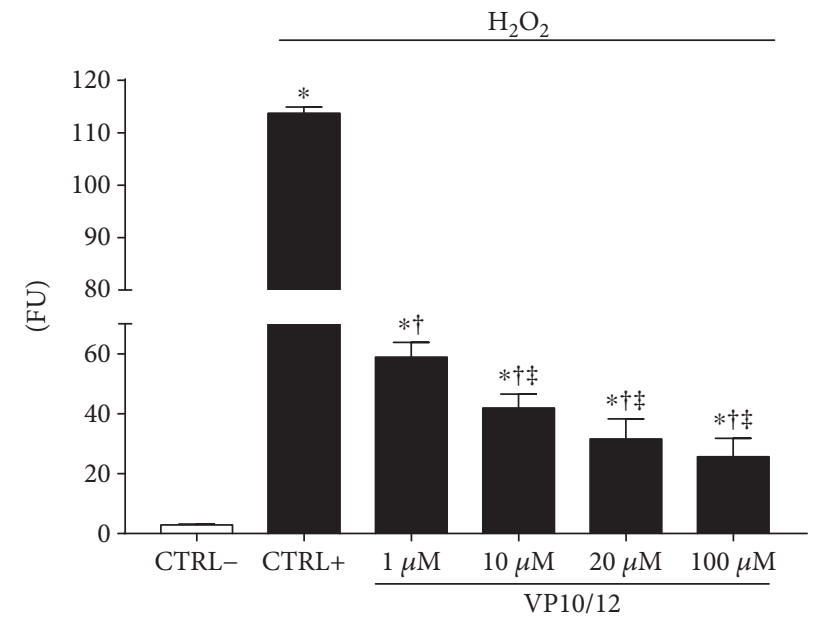

(a)

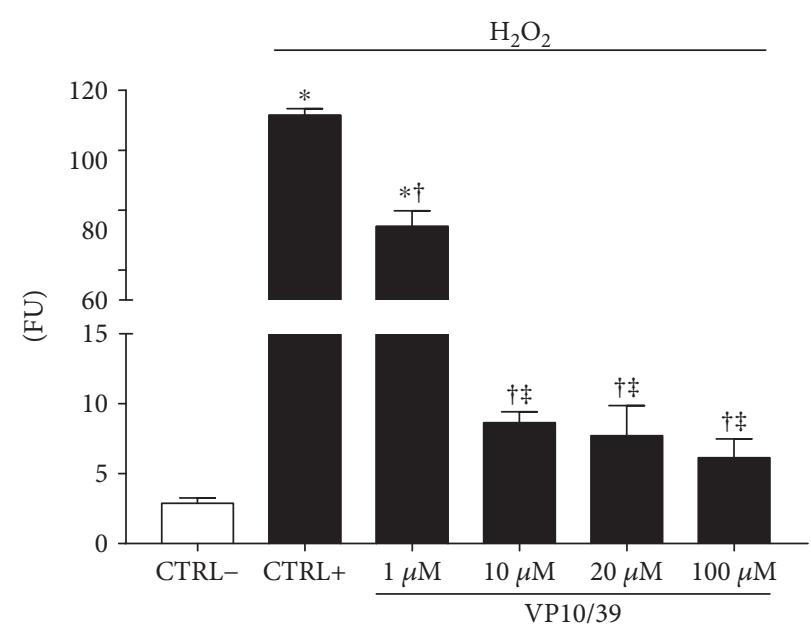

(b)

FIGURE 4: VP10/12 and VP10/39 decreased ROS concentration in ARPE-19 cells challenged with $\mathrm{H}_{2} \mathrm{O}_{2} .{ }^{*} p<0.05$ versus CTRL- cells (cells that were not treated with $\mathrm{H}_{2} \mathrm{O}_{2}$ ), ${ }^{\dagger} p<0.05$ versus CTRL+ cells (cells that were treated with $\mathrm{H}_{2} \mathrm{O}_{2}$ ) ${ }^{\ddagger} p<0.05$ versus $1 \mu \mathrm{M}$ VP10/12 or VP10/39 treatment.

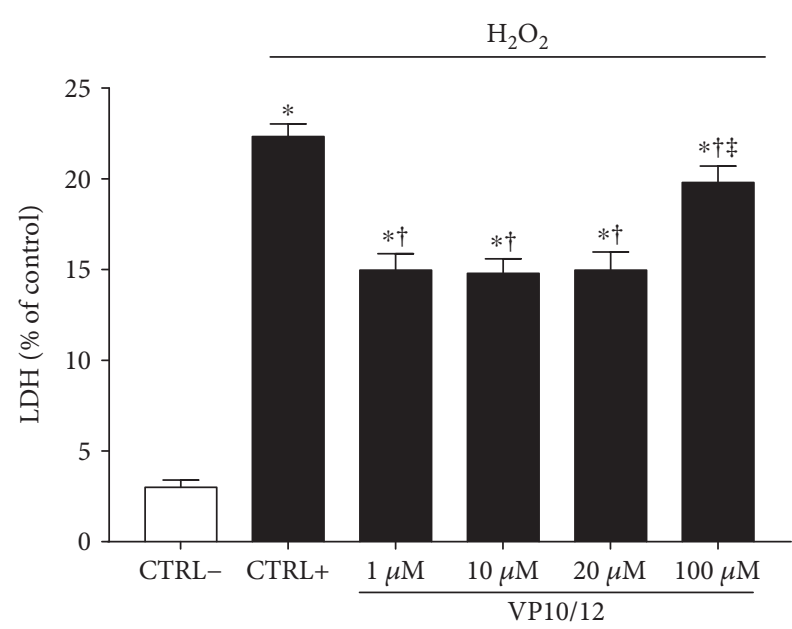

(a)

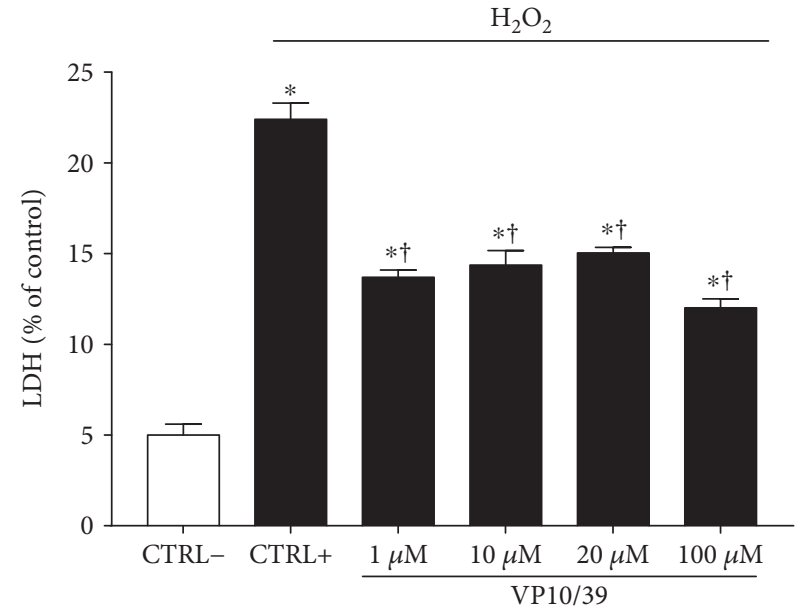

(b)

FIGURE 5: VP10/12 and VP10/39 decreased LDH release from ARPE-19 cells challenged with $\mathrm{H}_{2} \mathrm{O}_{2} .{ }^{*} p<0.05$ versus CTRL- cells (cells that were not treated with $\mathrm{H}_{2} \mathrm{O}_{2}$ ), ${ }^{\dagger} p<0.05$ versus CTRL+ cells (cells that were treated with $\mathrm{H}_{2} \mathrm{O}_{2}$ ), ${ }^{*} p<0.05$ versus $1 \mu \mathrm{M}$ VP10/12 or VP10/39 treatment.

a 1.5-fold decrease in LDH release, in comparison to positive control cells (CTRL+, ARPE-19 treated with $\mathrm{H}_{2} \mathrm{O}_{2}$, Figures 5(a) and 5(b)). However, $100 \mu \mathrm{M}$ VP10/12 increased LDH levels $(19.80 \pm 0.90)$ to values reported for CTRL+ cells $(22.33 \pm 0.70)$; thus curcumin-NO might exert toxic effects at high concentrations.

Oxidative damage affected cellular viability of ARPE-19 cells, given a significant $(p<0.05)$ decrease of ATP levels in CTRL+ cells, in comparison to CTRL- cells (Figures 6(a) and 6(b)). Treatment with VP10/12 and VP10/39 increased significantly ATP levels in ARPE-19 cells challenged with $\mathrm{H}_{2} \mathrm{O}_{2}$ (Figures 6(a) and 6(b)). Interestingly, VP10/39 treatment increased ARPE-19 cell viability in a dose-dependent manner.

Overall, these data indicated that both VP10/12 and VP10/39 are capable to protect ARPE-19 cells from oxidative damage; however, VP10/39 was more effective in decreasing ROS formation and $\mathrm{LDH}$ release than VP10/12, which at highest concentration $(100 \mu \mathrm{M})$ exerted a slight, still significant, toxic effect on ARPE-19 cells.

3.3. VP10/39 Induced HO-1. Resistance to oxidative stress of cells treated with VP10/12 and VP10/39 can be accounted not only to ROS-scavenging capability but also to induction of HO-1. We tested the capability of VP10/12 and VP10/39 to induce HO-1 in ARPE-19 by means of a HO-1 activity assay, which was previously set for ARPE-19 cells [45]. Only VP10/39 induced significantly $(p<0.05)$ HO- 1 in ARPE-19 at both tested concentrations, $10 \mu \mathrm{M}$ and $20 \mu \mathrm{M}$. VP10/12 at $10 \mu \mathrm{M}$ and $20 \mu \mathrm{M}$ concentrations did not alter HO- 1 activity in ARPE-19 cells, because no substantial differences were 


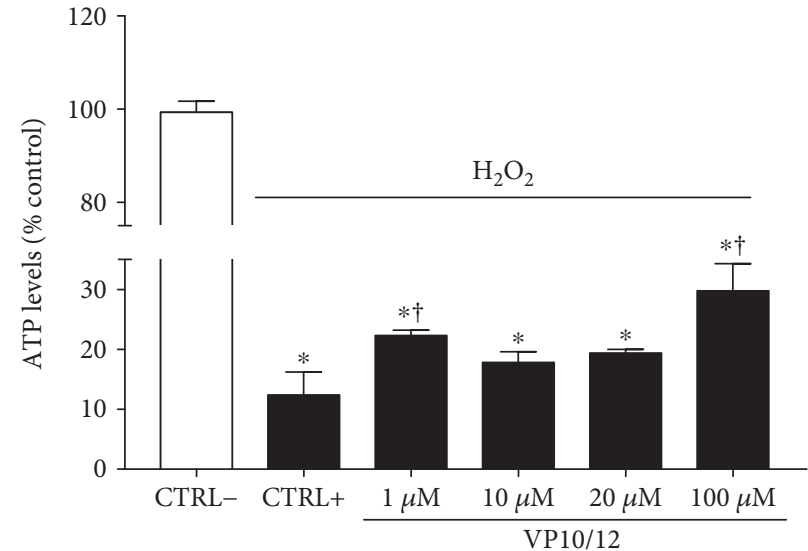

(a)

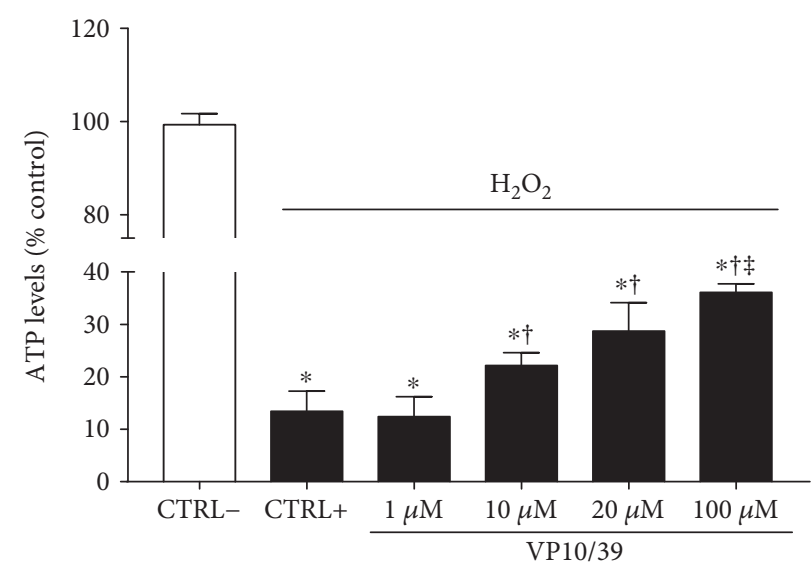

(b)

FIGURE 6: VP10/12 and VP10/39 viability of ARPE-19 cells challenged with $\mathrm{H}_{2} \mathrm{O}_{2} \cdot{ }^{*} p<0.05$ versus CTRL- cells (cells that were not treated with $\mathrm{H}_{2} \mathrm{O}_{2}$ ), ${ }^{\dagger} p<0.05$ versus CTRL+ cells (cells that were treated with $\mathrm{H}_{2} \mathrm{O}_{2}$ ) ${ }^{\ddagger} p<0.05$ versus $1 \mu \mathrm{M}$ VP10/12 or VP10/39 treatment.

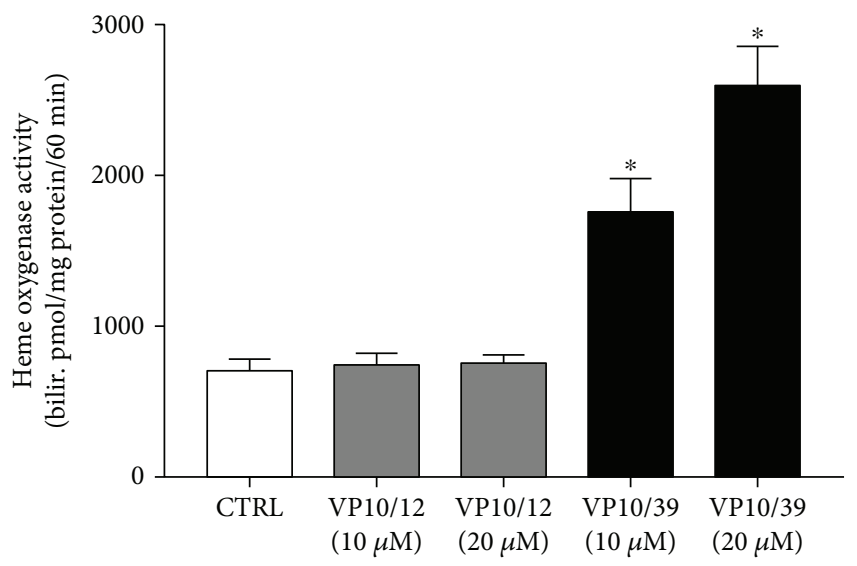

Figure 7: HO-1 induction by VP10/12 and VP10/39. ${ }^{*} p<0.05$ versus CTRL control cells.

found between control and VP10/12-treated cells (Figure 7). This result would explain the significant greater antioxidant activity of VP10/39, compared to VP10/12 (Figure 4).

In order to rationalize the capability of VP10/39 to induce HO-1, we built the model of Keap1 dimer, which, through association in a multiprotein complex, regulates the degradation of the nuclear factor Nrf2. In fact, under oxidative condition, Keap1 dimer dissociates and is not able to keep Nrf2 immobilized for ubiquitination by the E2 ubiquitin [51]. HO-1 induction can be promoted by stabilization of Nrf2 protein levels, therefore, by either inhibiting interaction between Keap1-DC/Nrf2 [46] or destabilizing the Keap1 dimer at the BTB domain [47]. In this perspective, we carried out semiflexible docking of VP10/12, VP10/39, curcumin, and CAPE at DC. Furthermore, we simulated Michael addition reaction (covalent docking) of ligands at the dimeric BTB domain of Keap1. Semiflexible docking of VP10/12 and VP10/39 at the DC domain of Keap1 was characterized by better docking scores (more negative) in comparison to
TABLE 1: Docking scores, covalent affinity, and $\Delta G_{\text {binding }}$ of docked ligands. Glide scores and covalent affinities are reported as arbitrary units; $\Delta G_{\text {binding }}$ are expressed in $\mathrm{Kcal} / \mathrm{mol}$.

\begin{tabular}{|c|c|c|c|c|}
\hline \multirow[t]{2}{*}{ Ligand } & \multicolumn{2}{|c|}{$\begin{array}{l}\text { Semiflexible docking } \\
\text { at DC domain }\end{array}$} & \multicolumn{2}{|c|}{$\begin{array}{c}\text { Covalent docking at BTB } \\
\text { domain }\end{array}$} \\
\hline & Glide score & $\Delta G_{\text {binding }}$ & Covalent affinity & $\Delta G_{\text {binding }}$ \\
\hline VP10/12 & -7.66 & -90.05 & -5.63 & -50.42 \\
\hline VP10/39 & -7.22 & -86.70 & -7.06 & -68.04 \\
\hline Curcumin & -5.74 & -67.50 & -4.07 & -47.38 \\
\hline CAPE & -4.08 & -62.50 & -3.33 & -41.67 \\
\hline
\end{tabular}

both curcumin and CAPE. VP10/12 showed a slightly better docking score at the DC domain (Glide score $=-7.66$ ), if compared to VP10/39 (Glide score $=-7.22$ ). However, poses (binding modes) of VP10/12 and VP10/39 are not similar to poses of known ligands of Keap1-DC. This trend was confirmed by MMGBSA rescoring (Table 1). On the contrary, curcumin (Glide score $=-5.74$ ) complexed at Keap1-DC alike a crystallized Keap1-DC/ligand complex (PDB:4ZY3) [46] (Figure 8(a)). Docking score differences between VP10/12 and VP10/39 at the Keap1 DC domain did not explain the capability of VP10/39 to induce HO-1. Worthy of note, MMGBSA binding energy was more negative for binding of ligands at the DC domain than binding of ligands at the BTB domain. However, MMGBSA rescoring for docking at DC and BTB cannot be compared, because of significant differences in simulated complex formation: noncovalent binding versus covalent binding. Covalent docking of the tested compounds at the Keap1-BTB domain revealed that VP10/39 covalently bound to Cys 151 of Keap1BTB showed better affinity $(-7.06)$ than VP10/12 $(-5.63)$, curcumin (-4.07), and CAPE (-3.33) (Figures 8(b), 8(c), and $8(\mathrm{~d})$ ). MMGBSA covalent docking rescoring confirmed that VP10/39 bound covalently to BTB domain with the lowest binding-free energy than other ligands. 


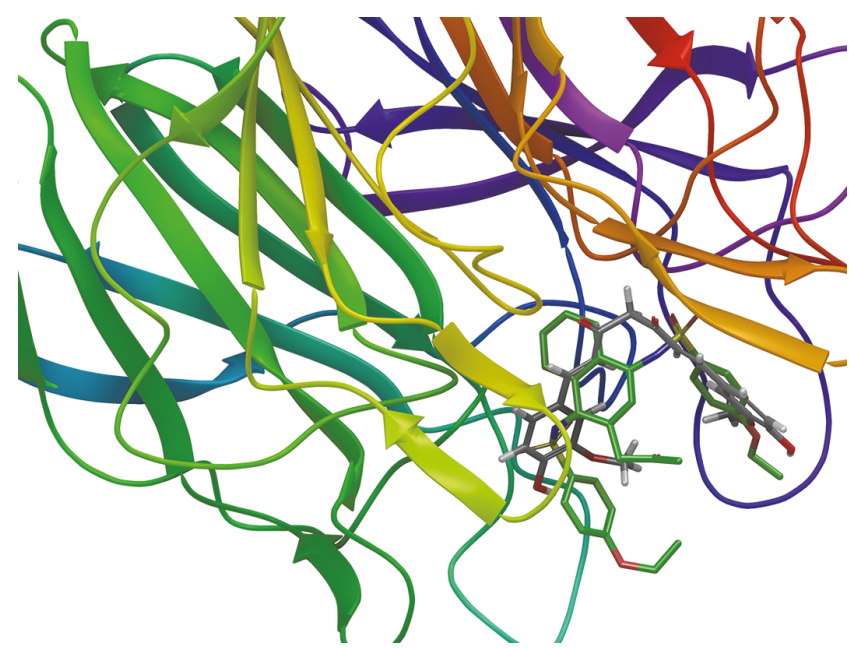

(a)

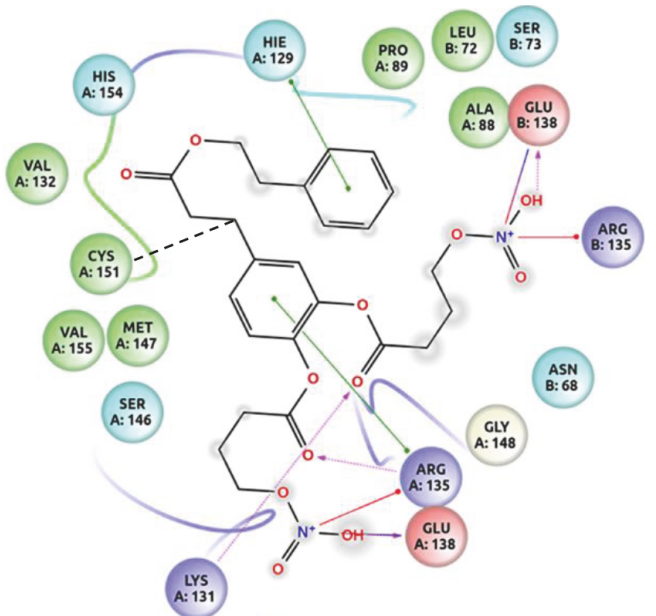

G: 134 .

(c)

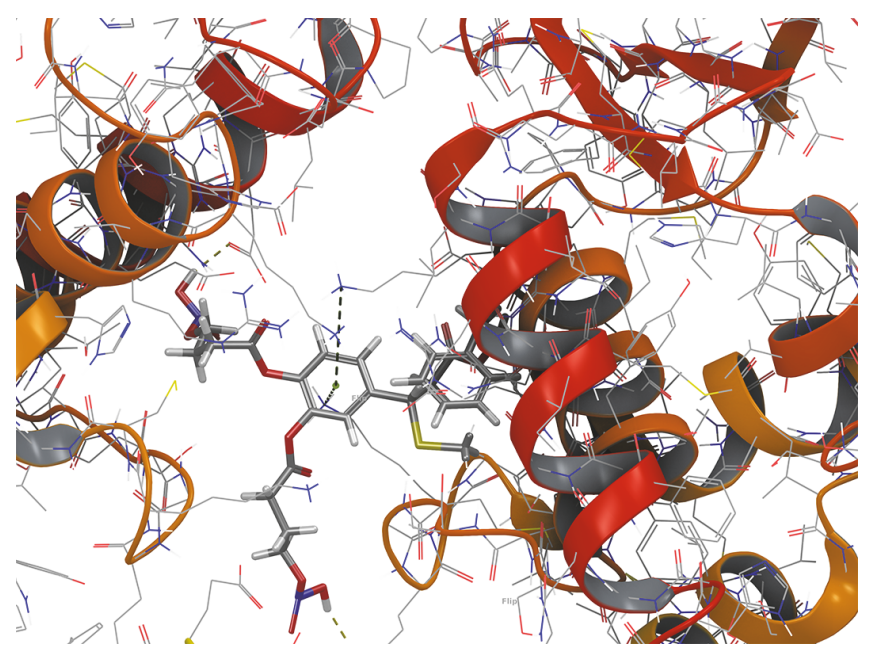

(b)

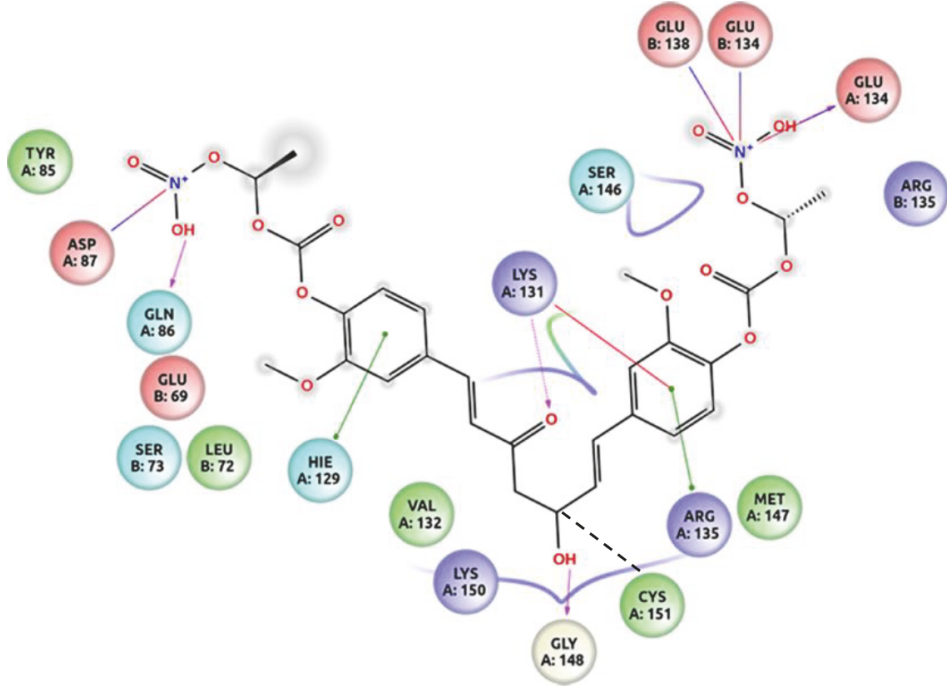

(d)

FIgure 8: Molecular docking into Keap1 domains. (a) Semiflexible docking at the Keap1-DC domain of curcumin (grey stick) and K67 (PDB:4ZY3, green stick). (b) Covalent docking-Michael addition at the Cys151 of the BTB domain of Keap1. (c) 2D pose representation of VP10/39 covalent bound (black hatched line) to Cys151 of the Keap1-BTB domain. (d) 2D pose representation of VP10/12 covalent bound (black hatched line) to Cys151 of the Keap1-BTB domain.

Indeed, VP10/39 can induce HO-1 by means of a covalent bound to Cys151 of Keap1-BTB, inhibiting Keap1 dimerization at the BTB domain.

\section{Discussion}

This study was aimed at designing new NO-releasing molecules to be potentially used for the treatment of AMD and DR. Oxidative stress, along with inflammation, is a hallmark of age-related retinal diseases such as AMD and DR, that lead to irreversible sight loss, if not correctly managed $[52,53]$. Currently, there are no approved drugs for the treatment of early phases of AMD and DR. Besides that, antiangiogenic and anti-inflammatory drugs are approved for treatment of diabetic macular edema and wet form of AMD, which are clinical forms of AMD and DR progression. Dysregulation of the HO-1 defense system against oxidative cell damage has been linked to AMD and DR progression. Antioxidant supplementation has been explored as a therapeutic strategy for diabetic retinopathy (clinicaltrial.gov "antioxidant AND diabetic retinopathy") and AMD (clinicaltrial.gov "antioxidant AND age related macular degeneration"). Furthermore, there are clinical trials about improvement of visual function in patients with diabetic retinopathy treated with curcumin supplementation (NCT02984813, NCT01646047). Besides preclinical promising results $[24,25,35]$, no clinical studies have been reported about either curcumin as a treatment of AMD or CAPE as treatment of both DR and AMD. We hereby hypothesized that a HO-1 inducer with a NOreleasing moiety would be promising for protection of retinal pigmented epithelium against oxidative stress, because $\mathrm{NO}$ can also induce HO-1. Both VP10/12 (curcumin-NO-releasing derivative) and VP10/39 (CAPE-NO-releasing derivative) were able to decrease ROS concentration and $\mathrm{LDH}$ 
release. Furthermore, both compounds increased cell viability in ARPE-19 cells, challenged with $\mathrm{H}_{2} \mathrm{O}_{2}$. However, VP10/39 was more effective in decreasing ROS and LDH in retinal pigmented epithelial cells treated with $\mathrm{H}_{2} \mathrm{O}_{2}$, in comparison to VP10/12.

Moreover, VP10/12 showed significant cell toxicity effects $(p<0.05)$ at the highest tested concentration $(100 \mu \mathrm{M})$; this result can be related either to a toxic dose of curcumin from hydrolyzed VP10/12 or to rapid and sustained release of NO by VP10/12.

The better activity of VP10/39, in comparison to VP10/12, can be explained by its capability to induce HO-1, as well as other CAPE derivatives [54], likely by means of covalent binding to Cys 151 of the Keap1-BTB domain, which is involved in the dimerization of Keap1. In fact, dimerization of Keap1 is a necessary condition for ubiquitination and degradation of $\mathrm{Nrf2}$; therefore, oligomerization of Keap1 is a good strategy for stabilizing Nrf2 and consequently to induce HO-1 [47].

\section{Conclusions}

In conclusion, VP10/39 is a promising compound capable of protective activity against oxidative damage on retinal pigmented epithelium. Therefore, this compound could be further developed as adjuvant antioxidant treatment of AMD and diabetic retinopathy.

\section{Conflicts of Interest}

The authors declare that they have no conflicts of interest.

\section{Acknowledgments}

This work was supported by the National Grant PRIN 2015JXE7E8 from the Ministry of Education, University and Research (MIUR).

\section{References}

[1] J. G. Hollyfield, V. L. Bonilha, M. E. Rayborn et al., "Oxidative damage-induced inflammation initiates age-related macular degeneration," Nature Medicine, vol. 14, no. 2, pp. 194-198, 2008.

[2] L. A. Donoso, D. Kim, A. Frost, A. Callahan, and G. Hageman, "The role of inflammation in the pathogenesis of age-related macular degeneration," Survey of Ophthalmology, vol. 51, no. 2, pp. 137-152, 2006.

[3] J. K. Shen, A. Dong, S. F. Hackett, W. R. Bell, W. R. Green, and P. A. Campochiaro, "Oxidative damage in age-related macular degeneration," Histology and Histopathology, vol. 22, no. 12, pp. 1301-1308, 2007.

[4] S. A. Madsen-Bouterse and R. A. Kowluru, "Oxidative stress and diabetic retinopathy: pathophysiological mechanisms and treatment perspectives," Reviews in Endocrine and Metabolic Disorders, vol. 9, no. 4, pp. 315-327, 2008.

[5] T. S. Kern, "Contributions of inflammatory processes to the development of the early stages of diabetic retinopathy," Experimental Diabetes Research, vol. 2007, Article ID 95103, 14 pages, 2007.
[6] A. Loboda, M. Damulewicz, E. Pyza, A. Jozkowicz, and J. Dulak, "Role of Nrf2/HO-1 system in development, oxidative stress response and diseases: an evolutionarily conserved mechanism," Cellular and Molecular Life Sciences, vol. 73, no. 17, pp. 3221-3247, 2016.

[7] Z. Zhao, Y. Chen, J. Wang et al., "Age-related retinopathy in Nrf2-deficient mice," PLoS One, vol. 6, no. 4, article e19456, 2011.

[8] M. Cukiernik, S. Mukherjee, D. Downey, and S. Chakabarti, "Heme oxygenase in the retina in diabetes," Current Eye Research, vol. 27, no. 5, pp. 301-308, 2003.

[9] R. Stocker, "Induction of haem oxygenase as a defense against oxidative stress," Free Radical Research Communications, vol. 9, no. 2, pp. 101-112, 1990.

[10] L. Cosso, E. P. Maineri, N. Traverso et al., "Induction of heme oxygenase 1 in liver of spontaneously diabetic rats," Free Radical Research, vol. 34, no. 2, pp. 189-191, 2001.

[11] J. L. da Silva, R. A. Stoltz, M. W. Dunn, N. G. Abraham, and S. Shibahara, "Diminished heme oxygenase-1 mRNA expression in RPE cells from diabetic donors as quantitated by competitive RT/PCR," Current Eye Research, vol. 16, no. 4, pp. 380-386, 1997.

[12] H. Hatcher, R. Planalp, J. Cho, F. M. Torti, and S. V. Torti, "Curcumin: from ancient medicine to current clinical trials," Cellular and Molecular Life Sciences, vol. 65, no. 11, pp. 1631-1652, 2008.

[13] A. Goel, A. B. Kunnumakkara, and B. B. Aggarwal, "Curcumin as "curecumin": from kitchen to clinic," Biochemical Pharmacology, vol. 75, no. 4, pp. 787-809, 2008.

[14] S. Shishodia, H. M. Amin, R. Lai, and B. B. Aggarwal, "Curcumin (diferuloylmethane) inhibits constitutive NF- $\kappa$ B activation, induces G1/S arrest, suppresses proliferation, and induces apoptosis in mantle cell lymphoma," Biochemical Pharmacology, vol. 70, no. 5, pp. 700-713, 2005.

[15] Y. Abe, S. Hashimoto, and T. Horie, "Curcumin inhibition of inflammatory cytokine production by human peripheral blood monocytes and alveolar macrophages," Pharmacological Research, vol. 39, no. 1, pp. 41-47, 1999.

[16] A. C. Reddy and B. R. Lokesh, "Studies on spice principles as antioxidants in the inhibition of lipid peroxidation of rat liver microsomes," Molecular and Cellular Biochemistry, vol. 111, no. 1-2, pp. 117-124, 1992.

[17] M. T. Huang, T. Lysz, T. Ferraro, T. F. Abidi, J. D. Laskin, and A. H. Conney, "Inhibitory effects of curcumin on in vitro lipoxygenase and cyclooxygenase activities in mouse epidermis," Cancer Research, vol. 51, no. 3, pp. 813-819, 1991.

[18] S. Singh and B. B. Aggarwal, "Activation of transcription factor $\mathrm{NF}-\kappa \mathrm{B}$ is suppressed by curcumin (diferuloylmethane)," Journal of Biological Chemistry, vol. 270, no. 50, pp. 24995-25000, 1995.

[19] J. H. Woo, Y. H. Kim, Y. J. Choi et al., "Molecular mechanisms of curcumin-induced cytotoxicity: induction of apoptosis through generation of reactive oxygen species, downregulation of $\mathrm{Bcl}-\mathrm{XL}$ and $\mathrm{IAP}$, the release of cytochrome $\mathrm{c}$ and inhibition of Akt," Carcinogenesis, vol. 24, no. 7, pp. 1199-1208, 2003.

[20] M. Susan and M. N. Rao, "Induction of glutathione S-transferase activity by curcumin in mice," Arzneimittel-Forschung, vol. 42, no. 7, pp. 962-964, 1992.

[21] G. Scapagnini, C. Colombrita, M. Amadio et al., "Curcumin activates defensive genes and protects neurons against 
oxidative stress," Antioxidants \& Redox Signaling, vol. 8, no. 3-4, pp. 395-403, 2006.

[22] E. Balogun, M. Hoque, P. Gong et al., "Curcumin activates the haem oxygenase-1 gene via regulation of Nrf2 and the antioxidant-responsive element," The Biochemical Journal, vol. 371, Part 3, pp. 887-895, 2003.

[23] V. Pittala, L. Vanella, L. Salerno et al., "Effects of polyphenolic derivatives on heme oxygenase-system in metabolic dysfunctions," Current Medicinal Chemistry, vol. 24, 2017.

[24] J. M. Woo, D. Y. Shin, S. J. Lee et al., "Curcumin protects retinal pigment epithelial cells against oxidative stress via induction of heme oxygenase-1 expression and reduction of reactive oxygen," Molecular Vision, vol. 18, pp. 901-908, 2012.

[25] R. A. Kowluru and M. Kanwar, "Effects of curcumin on retinal oxidative stress and inflammation in diabetes," Nutrition \& Metabolism, vol. 4, p. 8, 2007.

[26] S. Son and B. A. Lewis, "Free radical scavenging and antioxidative activity of caffeic acid amide and ester analogues: structure-activity relationship," Journal of Agricultural and Food Chemistry, vol. 50, no. 3, pp. 468-472, 2002.

[27] P. Michaluart, J. L. Masferrer, A. M. Carothers et al., "Inhibitory effects of caffeic acid phenethyl ester on the activity and expression of cyclooxygenase-2 in human oral epithelial cells and in a rat model of inflammation," Cancer Research, vol. 59, no. 10, pp. 2347-2352, 1999.

[28] J. Tan, Z. Ma, L. Han et al., "Caffeic acid phenethyl ester possesses potent cardioprotective effects in a rabbit model of acute myocardial ischemia-reperfusion injury," American Journal of Physiology - Heart and Circulatory Physiology, vol. 289, no. 5, pp. H2265-H2271, 2005.

[29] X. Wei, L. Zhao, Z. Ma et al., "Caffeic acid phenethyl ester prevents neonatal hypoxic-ischaemic brain injury," Brain, vol. 127, Part 12, pp. 2629-2635, 2004.

[30] K. Hishikawa, T. Nakaki, and T. Fujita, "Oral flavonoid supplementation attenuates atherosclerosis development in apolipoprotein E-deficient mice," Arteriosclerosis, Thrombosis, and Vascular Biology, vol. 25, no. 2, pp. 442-446, 2005.

[31] V. Pittala, L. Salerno, G. Romeo, R. Acquaviva, C. Di Giacomo, and V. Sorrenti, "Therapeutic potential of caffeic acid phenethyl ester (CAPE) in diabetes," Current Medicinal Chemistry, 2016.

[32] X. Wang, S. Stavchansky, B. Zhao, J. A. Bynum, S. M. Kerwin, and P. D. Bowman, "Cytoprotection of human endothelial cells from menadione cytotoxicity by caffeic acid phenethyl ester: the role of heme oxygenase-1," European Journal of Pharmacology, vol. 591, no. 1-3, pp. 28-35, 2008.

[33] J. K. Kim and H. D. Jang, "Nrf2-mediated HO-1 induction coupled with the ERK signaling pathway contributes to indirect antioxidant capacity of caffeic acid phenethyl ester in HepG2 cells," International Journal of Molecular Sciences, vol. 15, no. 7, pp. 12149-12165, 2014.

[34] X. Wang, S. Stavchansky, S. M. Kerwin, and P. D. Bowman, "Structure-activity relationships in the cytoprotective effect of caffeic acid phenethyl ester (CAPE) and fluorinated derivatives: effects on heme oxygenase-1 induction and antioxidant activities," European Journal of Pharmacology, vol. 635, no. 1-3, pp. 16-22, 2010.

[35] S. H. Paeng, W. K. Jung, W. S. Park et al., "Caffeic acid phenethyl ester reduces the secretion of vascular endothelial growth factor through the inhibition of the ROS, PI3K and HIF- $1 \alpha$ signaling pathways in human retinal pigment epithelial cells under hypoxic conditions," International Journal of Molecular Medicine, vol. 35, no. 5, pp. 1419-1426, 2015.

[36] R. Foresti, J. E. Clark, C. J. Green, and R. Motterlini, "Thiol compounds interact with nitric oxide in regulating heme oxygenase-1 induction in endothelial cells. Involvement of superoxide and peroxynitrite anions," The Journal of Biological Chemistry, vol. 272, no. 29, pp. 18411-18417, 1997.

[37] I. M. Goldstein, P. Ostwald, and S. Roth, "Nitric oxide: a review of its role in retinal function and disease," Vision Research, vol. 36, no. 18, pp. 2979-2994, 1996.

[38] N. Toda and M. Nakanishi-Toda, "Nitric oxide: ocular blood flow, glaucoma, and diabetic retinopathy," Progress in Retinal and Eye Research, vol. 26, no. 3, pp. 205-238, 2007.

[39] G. A. Garcia, P. Ngai, S. Mosaed, and K. Y. Lin, "Critical evaluation of latanoprostene bunod in the treatment of glaucoma," Clinical Ophthalmology, vol. 10, pp. 2035-2050, 2016.

[40] R. Foresti and R. Motterlini, "The heme oxygenase pathway and its interaction with nitric oxide in the control of cellular homeostasis," Free Radical Research, vol. 31, no. 6, pp. 459-475, 1999.

[41] K. S. Ramos, H. Lin, and J. J. McGrath, "Modulation of cyclic guanosine monophosphate levels in cultured aortic smooth muscle cells by carbon monoxide," Biochemical Pharmacology, vol. 38, no. 8, pp. 1368-1370, 1989.

[42] C. L. Hartsfield, J. Alam, J. L. Cook, and A. M. Choi, "Regulation of heme oxygenase-1 gene expression in vascular smooth muscle cells by nitric oxide," The American Journal of Physiology, vol. 273, no. 5, Part 1, pp. L980-L988, 1997.

[43] P. K. Datta and E. A. Lianos, "Nitric oxide induces heme oxygenase-1 gene expression in mesangial cells," Kidney International, vol. 55, no. 5, pp. 1734-1739, 1999.

[44] K. Chen and M. D. Maines, "Nitric oxide induces heme oxygenase-1 via mitogen-activated protein kinases ERK and p38," Cellular and Molecular Biology, vol. 46, no. 3, pp. 609-617, 2000.

[45] R. Foresti, C. Bucolo, C. M. Platania, F. Drago, J. L. DuboisRande, and R. Motterlini, "Nrf2 activators modulate oxidative stress responses and bioenergetic profiles of human retinal epithelial cells cultured in normal or high glucose conditions," Pharmacological Research, vol. 99, pp. 296-307, 2015.

[46] T. G. Davies, W. E. Wixted, J. E. Coyle et al., "Monoacidic inhibitors of the Kelch-like ECH-associated protein 1: nuclear factor erythroid 2-related factor 2 (Keap1:Nrf2) proteinprotein interaction with high cell potency identified by fragment-based discovery," Journal of Medicinal Chemistry, vol. 59, no. 8, pp. 3991-4006, 2016.

[47] C. Huerta, X. Jiang, I. Trevino et al., "Characterization of novel small-molecule Nrf2 activators: structural and biochemical validation of stereospecific Keap1 binding," Biochimica et Biophysica Acta (BBA) - General Subjects, vol. 1860, no. 11, Part A, pp. 2537-2552, 2016.

[48] J. Li, R. Abel, K. Zhu, Y. Cao, S. Zhao, and R. A. Friesner, "The VSGB 2.0 model: a next generation energy model for high resolution protein structure modeling," Proteins, vol. 79, no. 10, pp. 2794-2812, 2011.

[49] T. Ogura, K. I. Tong, K. Mio et al., "Keap1 is a forked-stem dimer structure with two large spheres enclosing the intervening, double glycine repeat, and c-terminal domains," Proceedings of the National Academy of Sciences of the United States of America, vol. 107, no. 7, pp. 2842-2847, 2010.

[50] K. Zhu, K. W. Bonelli, J. R. Greenwood et al., "Docking covalent inhibitors: a parameter free approach to pose prediction 
and scoring," Journal of Chemical Information and Modeling, vol. 54, no. 7, pp. 1932-1940, 2014.

[51] P. Canning, F. J. Sorrell, and A. N. Bullock, "Structural basis of keap1 interactions with Nrf2," Free Radical Biology and Medicine, vol. 88, pp. 101-107, 2015.

[52] T. Matsuura, K. Takayama, H. Kaneko et al., "Nutritional supplementation inhibits the increase in serum malondialdehyde in patients with wet age-related macular degeneration," Oxidative Medicine and Cellular Longevity, vol. 2017, Article ID 9548767, 9 pages, 2017.

[53] C. Li, X. Miao, F. S. Li et al., "Oxidative stress-related mechanisms and antioxidant therapy in diabetic retinopathy," Oxidative Medicine and Cellular Longevity, vol. 2017, Article ID 9702820, 15 pages, 2017.

[54] V. Pittala, L. Vanella, L. Salerno et al., "Novel caffeic acid phenethyl ester (CAPE) analogues as inducers of heme oxygenase-1," Current Pharmaceutical Design, vol. 23, 2017. 


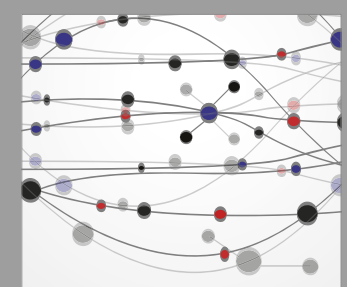

The Scientific World Journal
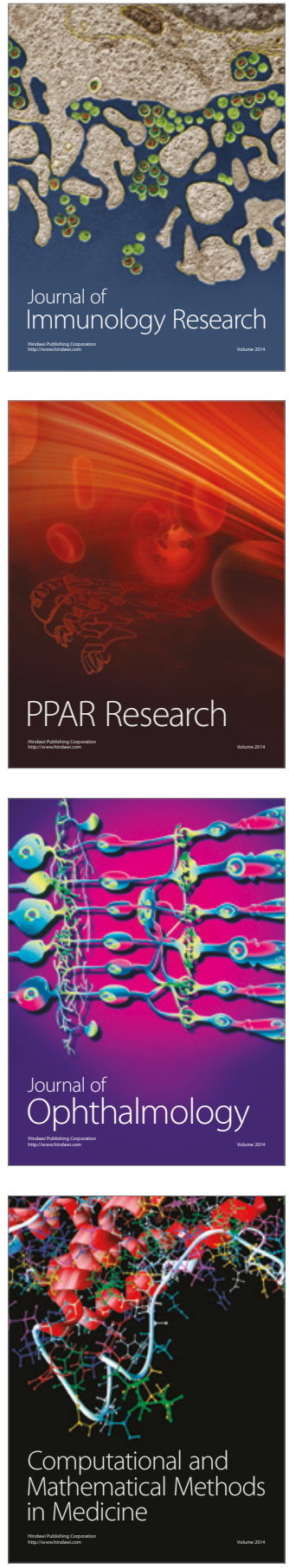

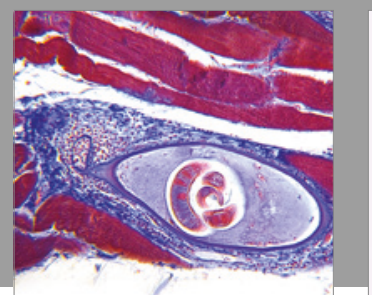

Gastroenterology Research and Practice
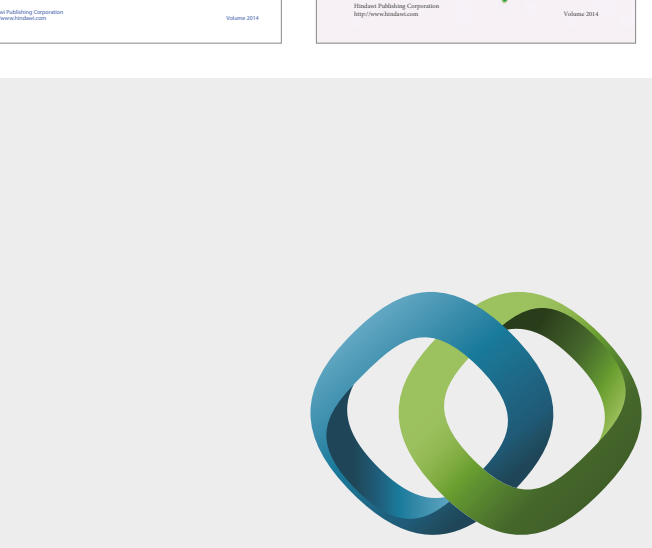

\section{Hindawi}

Submit your manuscripts at

https://www.hindawi.com
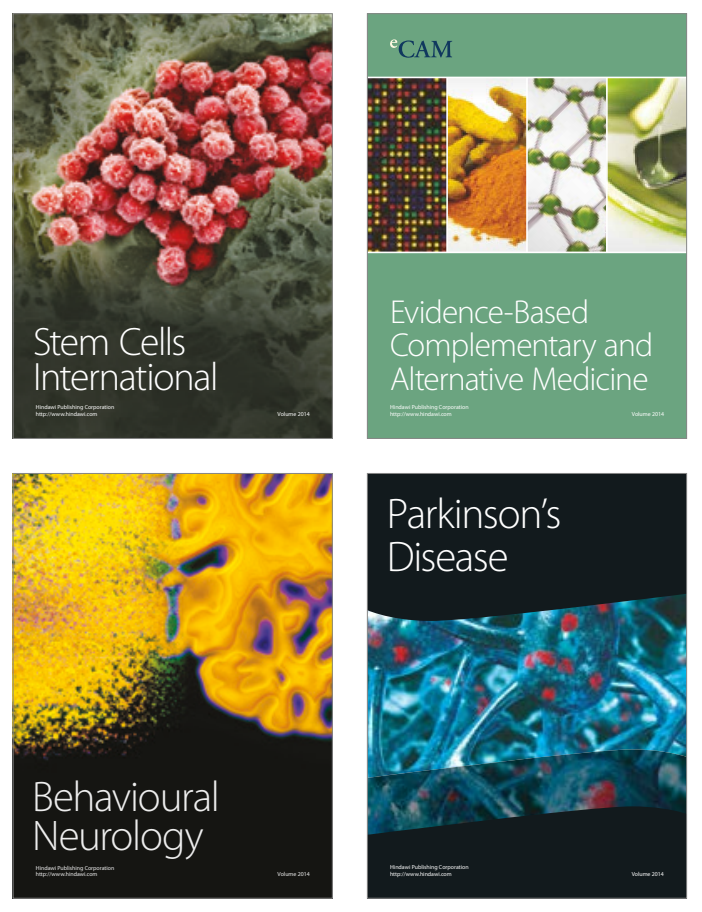
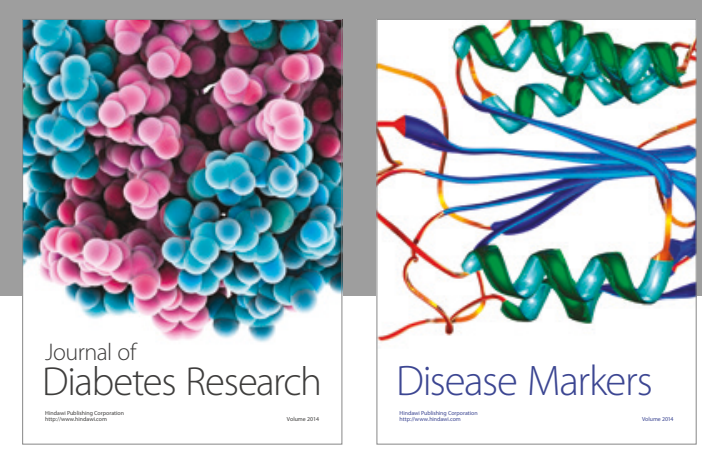

Disease Markers
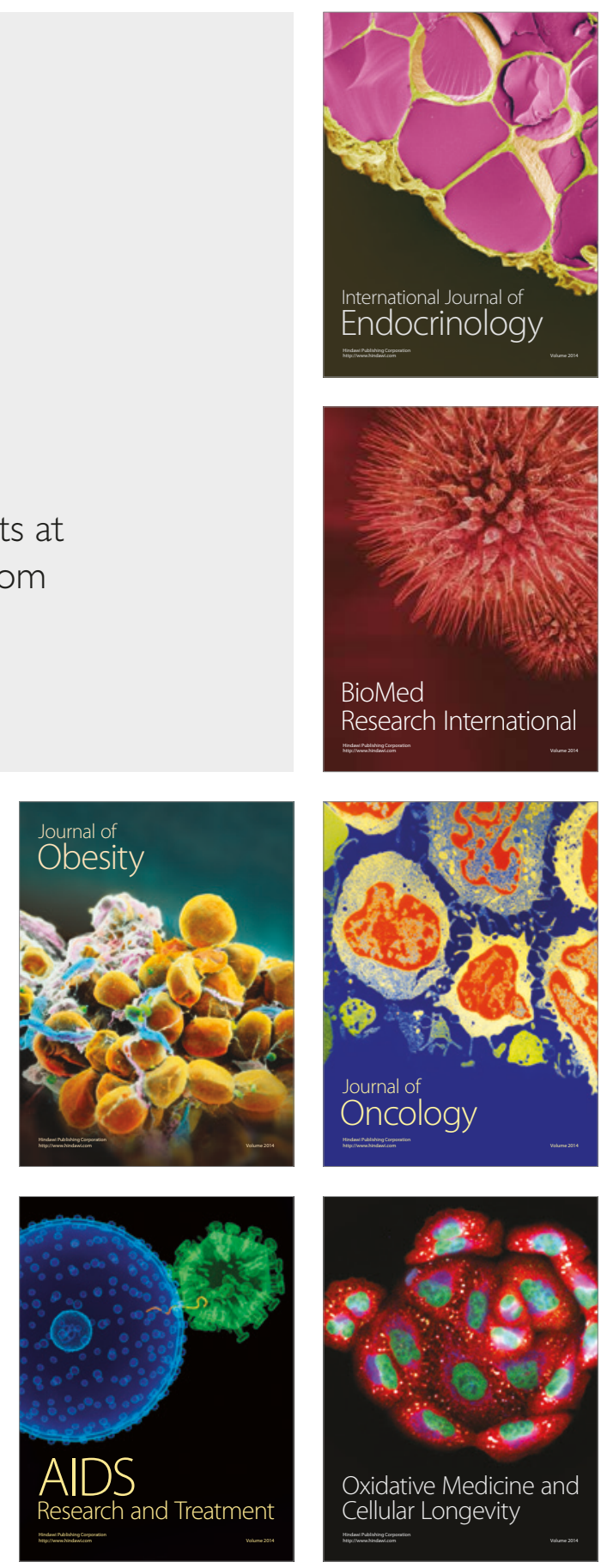